\title{
SELF-REGULATED LEARNING IMPLEMENTED BY THE STUDENTS OF ELEMENTARY SCHOOL IN BULELENG SUB-DISTRICT
}

\author{
Permatasai, N.P.I. \\ English Language Education, Universitas Pendidikan Ganesha \\ intan1538@gmail.com \\ Mahayanti, N.W.S. \\ English Language Education, Universitas Pendidikan Ganesha \\ mahayantisurya@yahoo.co.id \\ Nitiasih, P.K. \\ English Language Education, Universitas Pendidikan Ganesha \\ titiekjegeg@gmail.com
}

\begin{abstract}
This study highlights the implementation of each aspect of self-regulated learning in cyclical phase which was proposed by Zimmerman and Moylan (2009). With an aim to identify whether elementary school students in Buleleng Subdistrict implement self-regulated learning or not, this study used descriptive qualitatively research design to describe comprehensively the implementation of self-regulated learning in elementary school students. SDN 3 Banjar Jawa, SDN 4 Banyuasri, SD Laboratorium Undiksha, and SDN 4 Kampung Baru became the setting of this study because those schools have implemented curriculum 2013 which means that those schools have implicitly implemented self-regulated learning. There were 544 students from grade 1 until 6 which were chosen randomly as the subject of this study. The instruments used in this study were observation checklist, questionnaire which was consisted of 20 statements which had been distributed to subject of the study, and also interview guide which was used to interview several students from the subject of the study. The result of the study shows that most of elementary school students in Buleleng sub-district had implemented self-regulated learning.
\end{abstract}

Keywords: Curriculum 2013, elementary school students, self-regulated learning.

\section{INTRODUCTION}

Curriculum can be said as the basic and main component of education. UU nomor 20 tahun 2003 about national education system defines 'Curriculum is a set of plans and arrangements including the education goals, contents, learning materials, and learning methods'. Moreover, Allen (1992) as cited in Nunan (1997, p.6) states that curriculum is a general concept which considers the whole aspects such as the philosophical, social, and administrative factors contributing to the planning of educational program. Based on those explanations, curriculum is really important for the success of education. In Indonesia, education curriculum has undergone several changes depending on the situations and the needs of Indonesian education.

The newly curriculum that is implemented in Indonesia is Curriculum 2013 (K-13). In the implementation of this curriculum, the teachers are not required to develop a syllabus, the teachers are only focused on designing the innovative learning activities to improve the quality of the students (Nur \& Madkur, 2014, p. 125). Based on Permendikbud No. 67 tahun 2013, Curriculum 2013 is designed to prepare Indonesian students to the needs of 21 st century skills in this globalization era. Those 21 st century skills such as, problem solving, critical thinking, managing self, collaboration, creativity, innovation, and communication. All of those 21st century skills are inserted implicitly in the learning activities of Curriculum 2013.

Curriculum 2013 is also designed by Indonesian government to replace the school-based curriculum which is well-known as KTSP (Kurikulum Tingkat Satuan Pendidikan). The curriculum shift from 
school-based curriculum to K-13 is not a hasty decision which is taken by the government as it is not easy to design a model of curriculum to suit all schools in a country. The curriculum shift is admitted to involve a complex process which requires a good planning, enough time, funding, and support from all parties. Moreover, the shift from school-based curriculum to K-13 is the fixed combination among the problems occurred in the previous curriculum, demographic view, and benefits which are offered in the change (Ahmad, 2014, p.9).

Curriculum 2013 is expected to answer both the needs and challenges to improve the quality of education in Indonesia in which the learning process guided by the principles of scientific approach (Nur \& Madkur, 2014, p.130-131). Nugroho (2013) as cited in Said, Sutadji, and Sugandi (2016, p.67) stated that one of the learning models that can be integrated into scientific approach is cooperative learning model. According to Johnson, Johnson, \& Smith (2013, p.3), cooperative learning consists of small groups of students where the students learn how to work cooperatively with others, compete for enjoyment and motivation of learning, and responsible for its own learning and the learning of all team members. Cooperative learning model includes positive interdependence, individual accountability, and the use of collaborative skills among the students (Johnson \& Johnson as cited in Felder \& Rebecca, 2007, p.2). Since the student is the main focus in the learning process, student-centered learning is a part of cooperative learning model.

Student-centered learning tries to face one of the challenges in Indonesian education that is to make the students become autonomous learner. Student-centered learning is a method of teaching that shift the focus of instruction from the teacher to the students. In student-centered learning process, the students get opportunities to build the knowledge in order to gain a deep understanding as well as increasing the quality of students' knowledge and behavior (Wangid, 2014, p.161). Moreover, according to Wangid (2014, p.162), there are five psychological principles of student-centered learning; namely; (a) Metacognitive and cognitive factors which involve how the students think and establish the meaning of information and experience, (b) Affective factors which involve the students' beliefs, emotions, and motivation as the reactions-given to their learning situation, (c) Factors which illustrated the development of physical, intellectual, emotional, and social, (d) Personal and social factors which involve the ways of students learn with each other in a group work, (e) Individual differences factors which involve the individual's capacity to the learning process. Those principles of student-centered learning are close to the principle of self-regulated learning.

Furthermore, Wangid (2014, p.164) also stated three principles of self-regulated learning which are related to the fifth principles of student-centered learning. The first principle of self-regulated learning is self-regulation of cognition which focuses on the activities and abilities to use and monitor the learning strategies. This first principle of self-regulated learning is closely related to metacognitive and cognitive factors of student-centered learning. Then, the second principle of self-regulated learning is self-regulation of motivation and emotion which involve the emotional reactions of the students toward their learning. This principle of self-regulated learning is related to the affective factors and the other factors of student-centered learning which illustrated the development of emotional. Last, the third factor of self-regulated learning is self-regulation of behavior. This principle describes the students' efforts to monitor and manage their own learning which are actually close to the personal and social factors and also individual factors of student-centered learning.

In addition, American Psychological Association (1997) also stated that there are some principles of students-centered learning which is in line with the essence of self-regulated learning. It is the development of cognitive, affective, and psychomotor learning are the key aspects in every learning activities to manage the learning activities. Then, the essence of self-regulated learning can be seen in the implementation of students-centered learning where the students are required to be independent and be active learners in finding out anything the need through learning on their own (Wangid, 2014, p.162). Self-regulated learning concerns on how and why the learners being involved in learning process. The learners should know some aspects which are related to their academic achievement (Zimmerman, 1989, p.336). Self-regulated learners refer to the students who are aware of their strengths and weaknesses in learning and guided by personally set goals and task-related strategies (Zimmerman, 2002, p.65-66). Then, Zimmerman (2002, p.67) also 
proposed three cyclical phases of self-regulated learning such as forethought phase, performance phase, and self-reflection phase.

Furthermore, Zimmerman and Moylan (2009, p.301-305), they elaborated those phases as follows. First, forethought phase is the process which happened before the learners attempt to learn. This phase involves two main aspects such as task analysis and self-motivation. Task analysis consists of goal setting and strategic planning meanwhile, self-motivation concerns on students' perception toward the learning. Second, performance phase consists of two aspects such as self-control and self-observation. Self-control is the method which is chosen during the forethought phase. Meanwhile, self observation is self-record of personal events or self-experimentation to solve certain problems by looking at the reasons behind. The last, self-reflection phase consists of two aspects such as self-judgment and self-reaction. Self judgment concerns on self-evaluation toward result of the learning meanwhile, self-reaction is about learners' action taken toward result of the learning.

Based on the preliminary observation in SD Lab. Undiksha as the sample of elementary schools in Buleleng Sub-district which has implemented curriculum 2013 as their educational curriculum. During the implementation of curriculum 2013, it means that the school especially the teacher has tried to implement self-regulated learning for their students. This preliminary observation has a purpose to find out whether the students have implemented aspects of self-regulated learning in the performance phase or not. Then, from the preliminary observation in the classroom learning process, it showed that not all of the students have implemented self-regulatory skills in the classroom based on the aspects of self-regulated learning.

Since self-regulated learning can be implemented to foster the students to be autonomous learner therefore, the researcher is interested in conducting the identification of elementary school students' self-regulated learning and doing analysis toward the aspects of self-regulated learning in all cyclical phases. The researcher conducted this study in elementary schools in Buleleng Subdistrict which have implemented curriculum 2013. Those schools are SDN 3 Banjar Jawa, SDN 4 Banyuasri, SD Laboratorium Undiksha, and SDN 4 Kampung Baru. The data were collected by doing observation with the observation checklist, distributing questionnaire. The observation checklist was used to find out the implementation of self-regulated learning in the classroom. The questionnaire items were developed from each aspect of self-regulated learning in Zimmerman's cyclical phase. This study focuses on elementary schools which have implemented curriculum 2013 as their educational curriculum. It is because the implementation of student-centered learning as well as self-regulated learning of the students will be seen in the learning process. In the implementation of self-regulated learning, this study emphasizes on identifying aspects of self-regulated learning in Zimmerman (2002) and analyzing the aspects which are mostly implemented by the students.

\section{METHODS}

This study used descriptive qualitative design. The researcher conducted a qualitative descriptive research because generally the characteristics of qualitative research was suitable to identifying elementary school students' self-regulated learning. Moreover, descriptive qualitative research design was also suitable to analyze which aspects of self-regulated learning which are mostly implemented by elementary school student in Buleleng Sub-district.

This study was conducted in SDN 3 Banjar Jawa, SDN 4 Banyuasri, SD Laboratorium Undiksha, and SDN 4 Kampung Baru. Those elementary schools are located at Buleleng Sub-district. The researcher chose those elementary schools because those schools have fully implemented curriculum 2013 as their educational curriculum and self-regulated learning is part of curriculum 2013.

The subject of this study was the students in SDN 3 Banjar Jawa, SDN 4 Banyuasri, SD Laboratorium Undiksha, and SDN 4 Kampung Baru, at Buleleng Sub-district. In addition, the subject of the study was the students from grade 1 until grade 6 which was chosen randomly. The researcher conducted the study in elementary school students because elementary school is the beginner level of education which implements curriculum 2013 with self-regulatory skills inside it. If the learners have a success self-regulated learning since the elementary school level, it will train them to be self-regulated learners until the following levels of education. Elementary school students are in the process of developing their learning in which they can be 
responsible of their own learning. Furthermore, the object of this study was elementary school students' self-regulated learning and the aspects of self-regulated learning based on Zimmerman's cyclical phase which are mostly implemented by the students in their learning process.

After all of the data had been collected, the data will be analyzed in several steps. Data analysis refers to a systematic process, arranging the result of the questionnaire, transcript of recording, notes, and other materials which had been discovered through the process of data collection. Furthermore, analyzing the data in qualitative research design means that the researcher has to explain the real characteristics of the data and pay attention to the factors which build up the background of the data obtained. According to Miles and Huberman (1984), data analysis was done in four concurrent steps namely; data collection, data reduction, data display, and conclusion.

\section{FINDINGS AND DISCUSSION \\ Findings}

This study was conducted in four elementary schools which have implemented curriculum 2013 as their educational curriculum. Related to the implementation of curriculum 2013, this study has two main focuses. First, this study identified and tried to find out whether elementary school students in Buleleng Sub-district implement self-regulated learning or not. Then, the analysis of the aspects of self-regulated learning in cyclical phase which are mostly implemented by elementary school students in Buleleng Sub-district.

In this session, the implementation of self-regulated learning on four elementary schools in Buleleng Sub-district which have implemented curriculum 2013 were described in detail. The total amount of students were 544 students from grade 1 until 6 in 'SDN 3 Banjar Jawa', 'SDN 4 Banyuasri', 'SD Laboratorium Undiksha', and 'SDN 4 Kampung Baru'. In order to know whether the elementary school students have implemented each aspect of Zimmerman's cyclical phase, the researcher had distributed the questionnaire. The questionnaire used Guttman Scale which consisted of 'yes' and 'no' response. The questionnaire which consisted of 20 statements were designed to answer the first and second research questions of this study. The statements of the questionnaire were developed from the sixth aspects from each phase in the cyclical phase of Zimmerman and Moylan (2009) about self-regulated learning.

After distributing the questionnaire to the students, all information gained were analyzed qualitatively. In order to answer the first research questions, the information gained were analyzed qualitatively to present students' response toward all statements in the questionnaire descriptively. Then, based on the information gained through the questionnaire, the amount of students who agreed and did not agree toward all statements in the questionnaire will be presented through the table 1 below.

Table 1. The calculation of students' response toward each statement in the questionnaire

\begin{tabular}{clcc}
\hline $\begin{array}{c}\text { Number of } \\
\text { Item }\end{array}$ & \multicolumn{1}{c}{ Statements } & $\begin{array}{c}\text { Response } \\
\text { 'Yes' }\end{array}$ & $\begin{array}{c}\text { Response } \\
\text { 'No' }\end{array}$ \\
\hline 1 & $\begin{array}{l}\text { I have my own learning strategy to all subjects such as, I make } \\
\text { multiplication table to make me easier learning mathematics }\end{array}$ & 426 & 118 \\
2 & $\begin{array}{l}\text { I determine the maximum targeted score that I want to } \\
\text { achieve in every subject }\end{array}$ & 430 & 114 \\
3 & $\begin{array}{l}\text { I am sure that I can get a good score in all subjects } \\
\text { by joining a course }\end{array}$ & 417 & 127 \\
4 & $\begin{array}{l}\text { I always read subject book, depending on the subject schedule } \\
\text { that I will get for the following day }\end{array}$ & 461 & 83 \\
5 & $\begin{array}{l}\text { I belief that I can understand every material that will be } \\
\text { thought at class }\end{array}$ & 442 & 102 \\
6 & $\begin{array}{l}\text { I answer the exercises in the subject book or student's } \\
\text { worksheet before being asked by the teacher }\end{array}$ & 394 & 150 \\
7 & $\begin{array}{l}\text { I belief on my ability to do all tasks given by teacher } \\
\text { I am always diligent to answer the question given by the }\end{array}$ & 496 & 48 \\
8
\end{tabular}




\begin{tabular}{|c|c|c|c|}
\hline & teacher in the class & & \\
\hline 9 & $\begin{array}{l}\text { I always take a note of some important things from the } \\
\text { teacher's explanation without being asked by the teacher }\end{array}$ & 296 & 248 \\
\hline 10 & $\begin{array}{l}\text { I borrow my friend's note book if my note is not completed } \\
\text { yet or when I do not attend the meeting in the class }\end{array}$ & 372 & 172 \\
\hline 11 & $\begin{array}{l}\text { I try to finish the problems which are found in the class } \\
\text { before, I ask for a help from the teacher }\end{array}$ & 383 & 181 \\
\hline 12 & After school, I read again my note book at home & 328 & 216 \\
\hline 13 & I discuss my answer with my friend beside me & 369 & 175 \\
\hline 14 & I am not shy to compare my score with my classmates & 480 & 64 \\
\hline 15 & I want to accept suggestions from friends and teachers & 530 & 14 \\
\hline 16 & I often deliver my opinion in the group discussion activity & 462 & 82 \\
\hline 17 & $\begin{array}{l}\text { I always asking to teacher about the reason why I get a certain } \\
\text { score }\end{array}$ & 250 & 294 \\
\hline 18 & $\begin{array}{l}\text { I will study better if I get a score under minimum completion } \\
\text { criteria }\end{array}$ & 531 & 13 \\
\hline 19 & I will keep studying hard though I have gotten a good score & 525 & 19 \\
\hline 20 & $\begin{array}{l}\text { I always evaluate my weakness and strength in all subjects by } \\
\text { paying attention at the score that I got in every subject }\end{array}$ & 420 & 124 \\
\hline
\end{tabular}

From the table above, it can be seen that most of the elementary school students have implemented well self-regulated learning on most of the aspects in Zimmerman's cyclical phase. Although there were several statements which were not agreed by the students but, almost $75 \%$ of the students had shown a significant response to be self-regulated learners.

\section{RESULT AND DISCUSSION}

Self-regulated learning concerns on how and why the learners are being involved in learning process. The involvement of the students in the learning process is really important. Then, as what had been stated in the findings about the result of the questionnaire, elementary school students in Buleleng Sub-district especially at SDN 3 Banjar Jawa, SDN 4 Banyuasri, SD Laboratorium Undiksha, and SDN 4 Kampung Baru had been able to regulate their own learning by using certain self-regulatory skills or strategies. It was supported by the result of the questionnaire which showed that $77.25 \%$ of students have implemented well self-regulatory skills or strategies (statements in the questionnaire) in each aspect of self-regulated learning. Meanwhile, there was $22.75 \%$ of students who have not implemented self-regulatory skills or strategies of self regulated leaning.

According to Zimmerman (1989, p.336), the learners should know some aspects which are related to their academic achievement. Then, by implementing the aspects of self-regulated learning in the learning process, it can be assumed that elementary school students have been able to pay attention on their academic achievement. In other words, the students have something in their mind about how to achieve success academically. This finding was in line with a research conducted by Johnston (2016) about elementary school students' self-regulated learning and features of classroom contexts. The result of his research demonstrated that elementary school students' self-regulated learning was a positive and statistically significant predictor of children's academic achievement.

\section{CONCLUSION}

Based on the findings and discussion in the previous chapter, the present study can be concluded that elementary school students had done best in implementing self-regulatory skills as well as the aspects of self-regulated learning from each phase in Zimmerman's cyclical phase. Elementary school students at SDN 3 Banjar Jawa, SDN 4 Banyuasri, SD Laboratorium Undiksha, and SDN 4 Kampung Baru have implemented self-regulated learning in their learning process. It was supported by the result of the observation checklist which showed that the teachers have tried to design the activities in the class which train the students to perform their self-regulatory skills in performance phase such as, self-observation and 
self-control. Moreover, the result of the questionnaire also showed that $77.25 \%$ of students in those four schools agreed that they had implemented self-regulatory skills or strategies. Meanwhile, there was only $22.75 \%$ of students who did not agree towards the statements in the questionnaire. It confirmed that most of the students of elementary school that has been implemented curriculum 2013 have been able to regulate their own learning with self-regulatory strategies that they did.

Based on the discussion and conclusion, several suggestions which can be addressed to elementary school students, teachers, and further researcher are as follows.

For Elementary School Students

In the implementation of curriculum 2013, students must be able to regulate their learning which are responsible for their own learning. However, based on the identification toward the aspects of self-regulated learning, this study showed that elementary school students have not done well yet in implementing all the aspects of self-regulated learning. Thus, elementary schools students are suggested to regulate their own learning through setting their learning goals, monitoring the learning process, controlling their behavior and motivation toward their learning process, and reflecting to the result of their learning to get better academic achievement.

For Elementary School Teachers

The role of teacher in the learning process at school are really important. The teacher takes a role as the facilitator to help the students how to plan, monitor, organize, control, and evaluate their learning progress. The teacher also has the role to design activities which give opportunities for the students to explore by themselves. Moreover, the teacher's motivation for the students to learn will increase the students' motivation to learn and learn. When students feel that they got help and emotional support from the teacher, they will strive more in doing the tasks given, increasing their critical thinking, using self-regulatory strategies of learning, and finally achieving better achievement in learning.

For Further researchers

The researcher recommends further researchers to conduct a study about designing a learning model to enhance elementary school students' self-regulated learning in the phase which are rarely implemented by the students. This study will be the preliminary research for further researchers in designing the learning model.

\section{REFERENCES}

Ahmad, D. (2014). 'Understanding the 2013 Curriculum of English Teaching through the Teacherse and Policymakerse Perspectives', International Journal of Enhanced Research in Educational Development (IJERED), 2(4), pp. 6-15. doi: 2320-8708.

American Psychological Association. (1997). "Learner-Centered Psychological Principles: A Frameworks for School Reform and Redesign.

Felder, R.M., and Brent, R. (2007). Cooperative Learning. P.A. Mabrouk, ed., Active Learning: Models from the Analytical Sciences, ACS Symposium Series 970, Chapter 4, pp. 34-53. Washington, DC: American Chemical Society.

Johnston, Taylor, (2016). "Elementary School Students' Self-Regulated Learning and Features of Classroom Contexts". Undergraduate Honors Theses. Paper 47.

Johnson, D., Johnson, R. and Smith, K. (2013). Cooperative Learning: Improving University Instruction By Basing Practice On Validated Theory. Journal on Excellence in University Teaching.

Nur, M.R. and Madkur, A. (2015). 'Teachers' Voices On The 2013 Curriculum For English Instructional Activities', IJEE (Indonesian Journal of English Education), 1(2). doi: 10.15408/ijee.v1i2.1340.

Nunan, David. (1997). Syllabus Design. Newyork: Oxford University Press. 
Permendikbud Nomor 67 Tahun 2013 tentang Kerangka Dasar dan Struktur Kurikulum Sekolah Dasar I Madrasah Ibtidaiyah

Said, I., Sutadji, E. and Sugandi, M. (2016). The Scientific Approach-Based Cooperative Learning Tool for Vocational Students Vocation Program of Autotronic (Automotive Electronic) Engineering. IOSR Journal of Research \& Method in Education (IOSR-JRME), 6(3), pp.67-73. doi: 10.9790/7388-0603046773.

Undang-Undang Republik Indonesia Nomor 20 Tahun 2003 tentang Sistem Pendidikan Nasional

Wangid, M. N. (2014). Student-Centered Learning: Self-regulated Learning. International Conference on Fundamentals and Implementation of Education (ICFIE).

Zimmerman, B. J. (1989). A Social Cognitive View of Self-Regulated Academic Learning. Journal of Educational Psychology, 81, 329-339.

Zimmerman, B. J. (2002). Be-coming a Self-Regulated Learner: An Overview. Theory into Practice, 41, 64-70.

Zimmerman, B.J., \& Moylan, A.R., (2009). Self-regulation: Where metacognition and motivation intersect. In D.J. Hacker, J. Dunlosky, \& A.C. Graesser (Eds.), Handbook of Metacognition in Education (pp. 299-315). New York: Routledge. 